\title{
A Discourse of The Dependant's action For Loss of Support and The Influence of The New Constitutional Dispensation
}

\author{
Dr Nico P Swartz\& Mr Otto Itumeleng. \\ University of Botswana.Faculty of Social Sciences.Department of Law, Botswana, Gaborone.
}

\begin{abstract}
Roman law and the legal principle under that law is silent about an action for loss of support by the dependants of a breadwinner whose death was unlawfully caused by the defendant or wrongdoer. It was only under the Germanic custom that the life of a person had value capable of being estimated in monetary terms. The actions of the widow and children for loss of support are derived from the fact that they evoke support from the deceased during his lifetime. This paper also forged a solution to legal questions such as whether dependants can claim damages for loss of income in cases where the breadwinner or husband is negligent, and whether a husband can claim for loss of support due to the death of his wife? This study answers the question by relying on case law Union Government $v$ Lee in which the judge decided that the negligence of the breadwinner or husband did not render the dependant's action for loss of support a nullity. This decision in the Lee-case, which favoured dependants action for loss of support has its bearing or hinges upon the Germanic principles of wergeld and zoengeld. This Germanic principles and the Lee-case pave the way for such decision to be developed and moulded under constitutional premises so that it also be extended to dependant's action for loss of support to children born out of wedlock, polygamous marriages, religious marriages and gay and lesbian relationships.
\end{abstract}

Key words: Dependant's action for loss of support, constitutional dispensation, damages, zoengeld, wergeld, Germanic custom, LexAquilia, Digesta, Railway Administration.

\section{INTRODUCTION}

The gist of this study purports that a delict is a wrongful and culpable act which has harmful consequences. ${ }^{1}$ A delict engenders an action for damages. ${ }^{2}$ The law of delict evokes a compensatory function in that there must be some loss or damage for which the law makes compensation available. ${ }^{3}$ The object of this study is to discuss some basic principles of the dependant's action for loss of support, the assessment of damage as well as the quantification of the proper amount of damages under a constitutional dispensation on the law of damages.

\section{DESIGN/METHODOLOGY OF THE PAPER}

This paper rests solely on a theoretical study. The data acquired are going to be complemented by the author's own interpretations of court cases, text books and other scholarly constructs. The rendition or analysis of the author out of a myriad of sources will be utilised in order to pose a holistic subject matter on the principle of dependant's action for loss of income. This study will have to hark back to antiquity to achieve a holistic scope.After the attainment of a holistic nature of the paper, it is only then that this study will presents an innovative, thorough and systematic attempt to address the research questions raised therein. This article aims to present a strong, current and relevant theoretical or conceptual framework within which the inquiry is located.

\section{DEFINITION OF DAMAGES}

Damages is a monetary equivalent of damage awarded to a person with the object of eliminating as far as possible his past as well as future patrimonial, and where applicable, non-patrimonial damage. Money, in the

\footnotetext{
${ }^{1}$ www.saflii.org.za/za/cases/ZAWCHC/2007/51.html. Accessed 2015/06/15.

2 archive.org/stream/federalrailwayd01ingegoog/federalrailwayd01ingegoog_djvu.txt. Accessed 2015/06/15.

${ }^{3}$ apps.ufs.ac.za/courts/dl/system/courts/s...Amod v MMVAF.pdf.Accessed 2015/06/15.

DOI: $10.9790 / 0837-2109134865 \quad$ www.iosrjournals.org $\quad 48 \mid$ Page
}


tenor of this study, serves as an equivalent of damage. ${ }^{4}$ If damage is incapable of being compensated because it cannot be a true equivalent of the impaired interest(s), then satisfaction becomes irrelevant as a function of the law of delict. ${ }^{5}$ Satisfaction, thus implies, the reparation of damage in the form of injury to personality by effecting retribution for the wrong suffered by the plaintiff and by satisfying the plaintiff's (and or the community's) sense of justice. ${ }^{6}$ It can be deduced that satisfaction obliges the defendant to pay a sum of money to the plaintiff in proportion to the wrong inflicted on the latter.But, nevertheless, damages are a broad concept which consists of patrimonial as well as non-patrimonial loss (injury to personality). Authors such as Van der Walt, Reinecke, Boberg and Van der Merwe \& Oliver define damage only as patrimonial loss. They believe that patrimonial damage and injury to personality do not share any meaningful denominator. Other authors, however, such as McKerron, Pauw and Pont accept a wider concept of damage which includes non-patrimonial loss. ${ }^{7}$ As this study adopts the latter's views, it is therefore evident that injury to personality should also be seen as damage, which will engenders an action for loss of support to a dependant. ${ }^{8}$ Injury to personality, therefore is regulated by the action for pain and suffering, which evoke compensation. It is clear that if compensation is to be awarded for injury to personality - it therefore connotes that a wider concept of damage (ancillary to patrimonial loss), proposed by McKerron, Pauw and Pont also be accepted by the profession and judicature.

Thus, damages refer to harm in connection with someone's patrimony as well as his non-patrimonial loss or personality. ${ }^{9}$ The accommodation of the patrimonial as well as non-patrimonial loss thus provide a broader spectrum to the law of damages and enrich the field for the lawyer to exhaust as much as possible remedies for the dependant's action for loss of support, because of the wrongful death of a breadwinner. ${ }^{10}$ This study engages also a constitutional pioneering by vindicate a husband also as a dependant for an action for loss of income of a breadwinner-wife.

\section{RESULTS AND DISCUSSION \\ 4.1 HISTORICAL SETTING OF THE DEPENDANT'S ACTION FOR LOSS OF SUPPORT}

The action of dependants for the recovery of loss suffered as a result of the wrongful killing of the breadwinner was unknown to Roman law. ${ }^{11}$ This action or remedy, however, came to be recognised and firmly entrenched in Roman-Dutch law, under the influence of the Germanic custom concerning the institution of the zoengeldand the philosophy of natural law as developed by medieval and sixteenth century theologians. ${ }^{12}$

Initially, the dependant's action was not confined only to those classes of persons to whom the breadwinner had a legal obligation to support, but was also available to those whom the deceased was accustomed to support from a sense of duty. ${ }^{13}$ De Groot extended the action to those whom the deceased was accustomed to aliment $e x$ officio, for example his parents, his widow and his children. ${ }^{14}$ This passage demonstrates that the action was applicable at the instance of any dependant within his broad family, whom, he in fact, supported whether he was obliged to do so or not. ${ }^{15}$ The tendency to extend the dependant's action to any dependant enjoying de facto

${ }^{4}$ https://en.wikipedia.org/wiki/South_African_law_of_delict. (Accessed 2015/06/15.

${ }^{5}$ htpps://quizlet.com/43647443/law-of-delict-flash-cards/. Accessed 2015/06/15.

${ }^{6}$ archive.org/stream/dictionaryterms00abbogoog_djvu.txt. Accessed 2015/06/15.

7 www.saflii.org/za/cases/ZASCA/2008/141.html. Accessed 2015/06/15.

${ }^{8}$ https://en.wikipedia.org/wiki/South_African_law_of_delict. (Accessed 2015/06/15.

9 apps.ufs.ac.za/courts/dl/system/courts/s...Amod v MMVAF.pdf.Accessed 2015/06/15.

${ }^{10}$ www.saflii.org.za/za/cases/ZAWCHC/2007/51.html. Accessed 2015/06/15.

${ }^{11}$ apps.ufs.ac.za/courts/dl/system/courts/s...Amod v MMVAF.pdf.Accessed 2015/06/15.

${ }^{12}$ Hafiza Ismael Amod v Multilateral Motor Vehicle Accidents Fund. Case No"444/98 (29 September 1999).

www.saflii.org/za/cases/ZASCA/2012/130.rtf. Accessed 2015/06/15.

${ }^{13}$ www.justice.gov.za/sca/judgments/sca-1999/1999_santam.pdf. Accessed 2015/06/15.

${ }^{14}$ apps.ufs.ac.za/courts/dl/system/courts/s...Amod v MMVAF.pdf.Accessed 2015/06/15.

www.justice.gov.za/sca/judgments/sca_1999/1998_444_amod.pdf.

https://indiankanoon.org/doc/1332665/ De Groot. De Jure Belli ac Pacis (2.17.13). “[...] iis quos occisusalere ex officio solebat, putaparentibusuxoribusliberis [...]"

${ }^{15}$ apps.ufs.ac.za/courts/dl/system/courts/s...Amod v MMVAF.pdf.Accessed 2015/06/15.

DOI: 10.9790/0837-2109134865 www.iosrjournals.org $\quad 49 \mid$ Page


close familial relationship with the breadwinner is also manifested in Voet (9.2.11) who seeks to accord the dependant's action to the breadwinner's wife, children and the like ("uxori, liberis, similibusque"). ${ }^{16}$

\subsection{RATIONALE OF THE ACTION FOR LOSS OF SUPPORT}

It is stated in Evins $v$ Shield Insurance Co. Ltd.$^{17}$ that a claimant (the dependant) derived his right of action not through the deceased or from the estate, but from the fact that he has been injured by the death of the deceased and that the defendant is therefore responsible at law. ${ }^{18}$ Only a dependant to whom the deceased was under a legal duty to provide maintenance and support may sue, and in such action, the dependant must establish actual patrimonial loss, accrued and prospective, as a consequence of the death of the breadwinner. ${ }^{19}$ Where a deceased's estate generates sufficient income to support the dependants in full, no financial loss would be suffered as a result of the death of the deceased as per case law MacDonald and Others $v$ Road Accident Fund. ${ }^{20}$ Only actual material loss can be taken into account in an action of this kind. ${ }^{21}$ In Hulley $v \operatorname{Cox}^{22}$, it is mentioned that material loss can only be ascertained by balancing, on the one hand, the loss to him (the dependant) of the future pecuniary benefit, and on the other, any pecuniary advantage from whatever source comes to him (the dependant) by reason of the death of the deceased. ${ }^{23}$ The Judge decided in MacDonald and Others $v$ Road Accident Fund(supra)that the income on the fund in the estate came to the children by reason of the death of their father who had owed them a duty of support. ${ }^{24}$ But, it is also maintained in Lambrakis $v$ Santam Ltd ${ }^{25}$ that when judges assessing damages for loss of support in claims arising from wrongful death, allowance must also be made for any new source of income which the plaintiff has obtained as a result of the death of the deceased this being regarded as "accelerated benefits." ${ }^{26}$ The interest generated by the investment of the estate assets, payable to the children because of their father's death, did therefore constitute an accelerated benefit.

\subsection{IS A WIDOW AND HER MINOR CHILDREN BARRED FROM THE CLAIMING OF DAMAGES FOR THE COMBINED NEGLIGENCE OF THE DEFENDANT AND THE DECEASED?}

It is common knowledge in law that when a party is negligent then he or she forfeits any remedial action for benefits. ${ }^{27}$ This study tussle under this heading with the research question of whether the dependant will qualify for an action for loss of support where the deceased breadwinner was held to be negligent for his own death.

In Union Government (Minister of Railways) $v$ Lee $^{28}$, it has been established that a claim for damages by a widow or the minor children of a person whose death is alleged to have been caused by the negligence of the defendant is not barred by the fact that the death is found to have been caused by the combined negligence of the latter and the deceased. Dr. Lee died as a result of injuries received, whilst driving his motor car which came

\footnotetext{
${ }^{16}$ apps.ufs.ac.za/courts/dl/system/courts/s...Amod v MMVAF.pdf.Accessed 2015/06/15.

Paixao v Road Accident Fund (640/2011), [2012] ZASCA 130 (26 September 2012).

${ }^{17}$ www.saflii.org/za/cases/ZASCA/2008/141.rtf. Accessed 2015/06/15.

Evins v Shield Insurance Co Ltd 1980 (2) SA 814 (A).

${ }^{18}$ www.saflii.org.za/za/cases/ZAGPPHC/2009/16.html. Accessed 2015/06/15.

${ }^{19}$ saflii.org/za/cases/ZAWCHC/2011/215.html. Accessed 2015/06/15.

${ }^{20}$ saflii.org/za/cases/ZAWCHC/2011/215.html. Accessed 2015/06/15. MacDonald and Others v Road Accident Fund (453/2011) [2012] ZASCA 69, [2012] 4 All SA 15 (SCA) (24 May 2012).

${ }^{21}$ uir.unisa.ac.za/bitstream/handle/10500/2446/thesis.pdf.txt?sequence=2. Accessed 2015/06/15.

${ }^{22}$ saflii.org/za/cases/ZAWCHC/2011/215.html. Accessed 2015/06/15.

Hulley v Cox 1923 AD 234.

${ }^{23}$ saflii.org/za/cases/ZAWCHC/2011/215.html. Accessed 2015/06/15.

${ }^{24}$ www.saflii.org/za/cases/ZAECGHC/2011/61.html. Accessed 2015/06/15.

${ }^{25}$ saflii.org/za/cases/ZAWCHC/2011/215.html. Accessed 2015/06/15.

Lambrakis v Santam Ltd 2002 (3) SA 710 (SCA).

${ }^{26}$ saflii.org/za/cases/ZAWCHC/2011/215.html. Accessed 2015/06/15.

${ }^{27}$ www.saflii.org.za/za/cases/ZAGPPHC/2009/16.html. Accessed 2015/06/15.

${ }^{28}$ archive.org/stream/reportscasesdec00maygoog/reportscasesdec00maygoog_djvu.txt. Accessed 2015/06/15.

Union Government (Minister of Railways) v Lee 1927 AD 202.
}

DOI: 10.9790/0837-2109134865 www.iosrjournals.org


into collision with a train at a level crossing. His widow litigated and sued the Railway Administration on behalf of herself and her minor children for damages or loss of support. ${ }^{29}$ The jury found that the death of Dr. Lee was caused both by the negligence of the defendant and by the negligence of the deceased, Dr. Lee. ${ }^{30}$ There was some ambivalence to determine whose negligent act preponderate in order to establish liability. This ambivalence moved the jury to proportionate the negligence between the Minister of Railways (employer of the train driver and defendant) and Dr. Lee (whose dependants wants to lodge a claim for damages as a result of loss of support). The jury resolved therefore, that both Dr. Lee and the train driver could have done something to avoid the accident had they kept a proper look-out. ${ }^{31}$ The question then arises, what judgment must be entered to in an action brought by the widow of a deceased man, when the evidence showed that his death was caused by the combined negligence of the defendant (Railway Administration) and himself (the deceased). Under Roman Dutch Law, unlike in Roman law with its LexAquilia principle, the widow does not stand in the shoes of her husband, but has an independent right of action of her own and so have the children. ${ }^{32}$ This means that negligence of the husband would not render them incapable to sue a guilty party for loss of income of the wrongful death of her husband and their father. This aforementioned principle had been established by the Transvaal Court in the case of Jameson's Minors v C.S.A.R. ${ }^{33}$ It was suggested in the Jameson's case that the widow's right of action is not derived from the LexAquilia of Roman law at all, but rather from Germanic Custom. ${ }^{34}$ The LexAquilia caters only for damages to the deceased estate. Such principle fell short to an action for claiming of damages by the widow and the children and nullifies the tenor of this study.

The Germanic Custom accommodated the widow and her children under the principles of the wergild and zoengeld. As mentioned earlier, these two principles entailed that there are no grounds on which the negligence of the husband can be imputed to his widow, thus forfeited her claim for damages. ${ }^{35}$ Under Germanic Custom the life of a freeman had a value capable of being estimated in money. ${ }^{36}$ And by ancient criminal practices a payment had been exacted from the wrongdoer for the benefit of the family of the deceased. ${ }^{37}$ The compensation claimable is due to third parties that derived their rights from the fact that they have been injured by the death of the deceased and that the defendant is in law responsible for it. ${ }^{38}$

In the light of these renditions, the presiding judge in the Lee case decided that the negligence of Dr Lee does not bar the right of his widow and children to recover damages due to his death, which would not have occurred had not the Railway Administration been negligent also. The practice of zoengeld has disappeared from the modern law because of the introduction of public prosecution at the instance of the State, which

\footnotetext{
${ }^{29}$ archive.org/stream/federalrailwayd01ingegoog/federalrailwayd01ingegoog_djvu.txt. Accessed 2015/06/15.

${ }^{30}$ archive.org/stream/reportscasesdec00maygoog/reportscasesdec00maygoog_djvu.txt. Accessed 2015/06/15.
}

${ }^{31}$ archive.org/stream/reportscasesdec00maygoog/reportscasesdec00maygoog_djvu.txt. Accessed 2015/06/15.

${ }^{32}$ www.elaws.gov.bw/desplaylrpage.php?id=610\&dsp=2. Accessed 2015/06/15.

${ }^{33}$ Jameson's Minors v C.S.A.R. 1908 T.S. 575.

${ }^{34}$ archive.org/stream/dictionaryterms00abbogoog/dictionaryterms00abbogoog_djvu.txt. archive.org/stream/reportscasesdec00maygoog/reportscasesdec00maygoog_djvu.txt. Accessed 2015/06/15. Union Government $v$ Lee, p. 205. The Roman Law source of the modern action for damages for negligence is the LexAquilia. The LexAquilia conferred upon owners a right of action for damage done to their property and it was necessary, therefore, firstly, that the plaintiff should be an owner or someone in a like position such as a bona fide possessor or a person having a jus in re aliena and the damage recoverable was the pecuniary lose suffered by the owner because of his property in the thing damaged. The widow of a deceased man has no property in him and it is difficult, therefore, to see how her claim against the wrongdoer could be derived from the LexAquilia.

${ }^{35}$ Union Government $v$ Lee.

${ }^{36}$ www.archive.org/stream/ahistorygermani00walzgoog/ahistorygermani00walzgoog_djvu.txt. Accessed 2015/06/15.

${ }^{37}$ https://www.coursehero.com/file/p17g4nr/...ted-by-the-deceased/ Accessed 2015/06/15.

${ }^{38}$ Union Government v Lee.

www.saflii.org/za/cases/ZAECGHC/2011/61.html. Accssed 2015/06/15.

DOI: 10.9790/0837-2109134865 $\quad$ www.iosrjournals.org $\quad 51 \mid$ Page


leaving the civil remedy for damages, where available, intact. The Roman Law reception under civil and common law jurisdiction in the Digesta (9.1.3.; 9.3.1.5.; and 14.2.22.) 39 $^{3}$ Justinian, states that while a human life cannot be estimated or valued, nevertheless, where death is caused through malice or negligence, the widow and children, accustomed to receive pecuniary support from the deceased, are entitled to recover damages for the material loss sustained by them. ${ }^{40}$ The action of the widow and her children for loss of support was derived from the fact that they derived support from the deceased during his lifetime. ${ }^{41}$ And because of this factor she and her children have an action for loss of support.

The converse of the Lee-case is the South African Railways and Harbours $v$ Marias ${ }^{42}$ decision. In this case, the respondent, in her personal capacity and in her capacity as mother and natural guardian of her minor child, obtained a rule nisi in the Cape Provincial Division calling on the appellant to show cause why she should not be permitted to sue the appellant in forma pauperis for damages suffered by reason of the death of her husband in a railway accident. ${ }^{43}$ The respondent based her claim for damages upon the allegation that the death of her husband was caused by the negligent driving of a mixed goods and passenger train by a servant of the Railway Administration. ${ }^{44}$ The respondent's husband, Marais, died as a consequence of the derailment of the train. Marais was in possession of a valid second class ticket from WorcestertoTouws River. The conductor allocated to him a compartment in the guard's coach at the tail end of the train. Marais remained in the compartment until De Doorns was reached, where he left his compartment and joined the driver and fireman of the train on the engine-room and remained there until the derailment took place. ${ }^{45}$ As a result of the derailment, the driver and stoker of the train and Marais died.

The appellant, the Railway Administration and employer of the train driver, averred that in so far as the train driver exercised control over the train, he was acting within the scope of his employment. ${ }^{46}$ The Railway Administration further asserted that in so far as the train driver allowed Marais to travel in the engine-room, it was a personal and private act of the driver, which was beyond his (the train driver) authority and beyond the scope of his employment. ${ }^{47}$ The Railway Administration also maintained that if Marais had at the time of the derailment travelled in the guard's coach, which was allotted to him, he would not have been killed ${ }^{48}$. By this averment, the Railway Administration wanted to establish negligence and imputed it on Marais and the train driver in order to avoid liability for damages from the deceased's dependants for loss of support.

The Railway Administration also contended that no member of the public shall be allowed to travel on an engine-room, unless he is in possession of a printed or written permission from an authorised officer of the Administration. Marais was not in possession of such permission when he boarded the engine-room on the train. It is further alleged by the Railway Administration that it is not part of the duties of train drivers and stokers to make arrangements in regard to the transportation of passengers. ${ }^{49}$

It is evident from the literature that the derailment had occurred as a result of the negligence of the train driver employed by the appellant, the Railway Administration. ${ }^{50}$ The judge, however, contended that the test is not

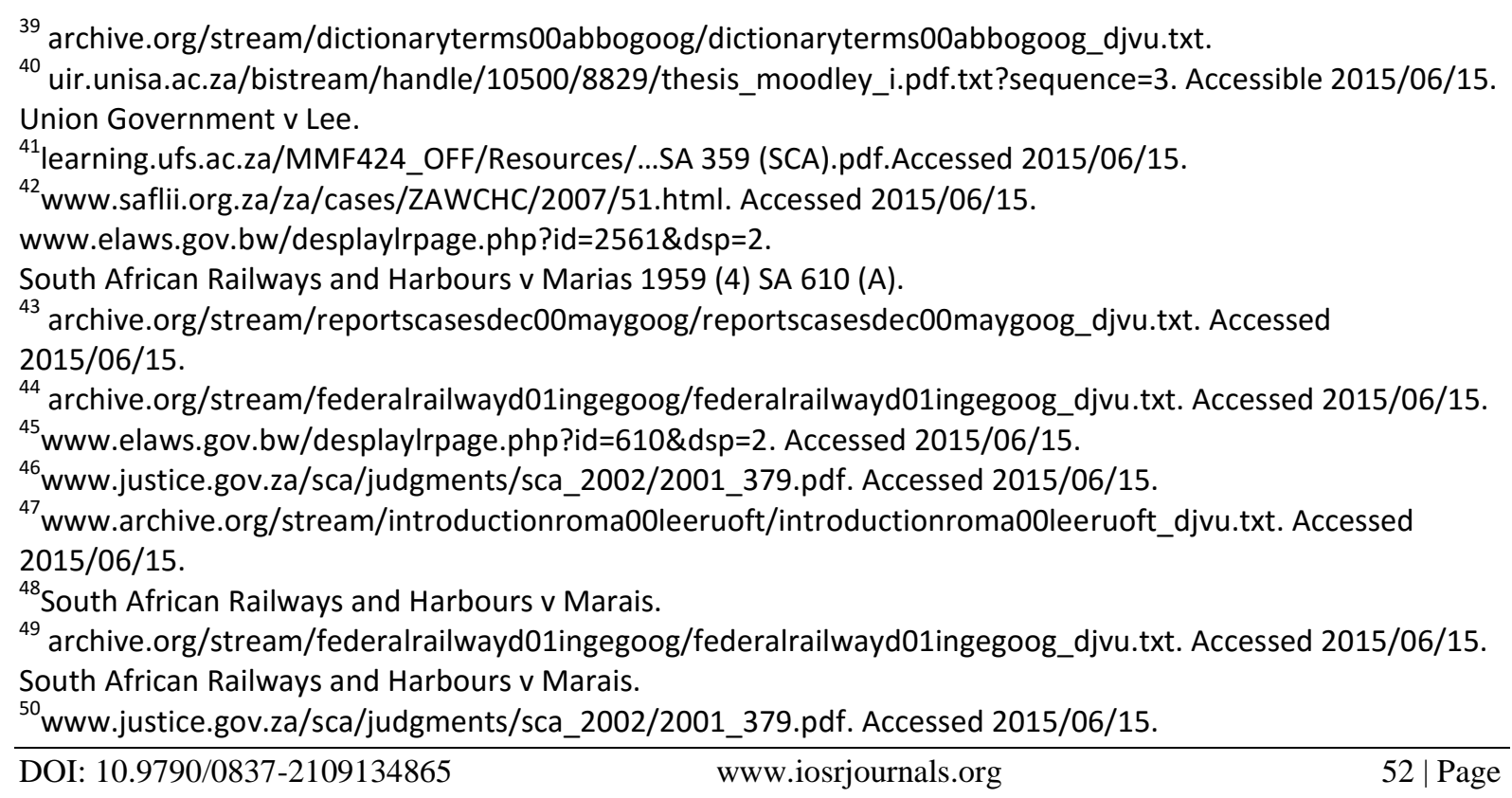


whether the act or omission complained of, occurred whilst the servant was engaged in the affairs of his master, but whether it constituted negligent performance of the work entrusted to the servant (the train driver) ${ }^{51}$ The leitmotiv of the present case is, irrespectiveoff, if the act or omission might have occurred whilst the servant was engaged in the affairs of his master, the master may under certain circumstances not be held liable. An example to explain this notion follows: for instance, a servant may, whilst engaged in the affairs of his master, assault a third person in order to satisfy a grudge of his own. Such assault would be quite unconnected with his master's work. ${ }^{52}$ In such a case the master would not be liable for the servant in committing the assault. Because the servant was not performing the work entrusted to him. This sentiment was bolstered in Mkize v Martens ${ }^{53}$, when Judge Innes said that for practical purposes a master is answerable for the torts of his servant committed in the course of his employment. ${ }^{54}$ Judge Innes stated further that an act done by a servant solely for his own interests and purposes, and outside his authority, is not done in the course of his employment, even though it may have been done during his employment. ${ }^{55}$ Another case that also touches on the point under consideration is Middleton $v$ Automobile Association of South Africa. ${ }^{56}$ In this case it was held that a master was not liable for an injury caused to a third party by the negligent driving of a servant where the servant, contrary to express instructions given by his master, had given a third party a lift. The ground of the decision was that, although the act complained of was done by the servant during his employment, it was not done by him in the course of his employment. $^{57}$

The work entrusted to the train driver in the Marais case was to drive the train and he had to do it in such a manner as not to injure anyone while doing so. ${ }^{58}$ It was not the work of the Railway Administration to transport passengers on the engine-room and if the driver chooses to do so, he was acting outside the scope of his employment. ${ }^{59}$ The transportation of Marais upon the engine-room of the train is entirely the driver's own act. ${ }^{60}$ It was clearly not done for the purpose of furthering his master's (Railway Administration) interests and was wholly outside the scope of his employment by conveying someone on his engine-room who had no right to be there. The judge decided in favour of the Railway Administration and said that Marais had no right to be in the engine-room and that the Railway Administration owed no duty to take care. ${ }^{61}$ The driver caused the death of the deceased and the Railway Administration is therefore not liable to the deceased dependant's for loss of support.

\subsection{WHETHER THE LOSS OF COMFORT AND SOCIETY OF THE PLAINTIFF'S WIFE AND THE LOSS OF HER ASSISTANCE IN THE CARE OF HIS CHILDREN BY HER ENTITLED A HUSBAND TO A CLAIM FOR PECUNIARY DAMAGES}

From time immemorial, the husband had always been the breadwinner of the family. This notion had been enshrined into the "hearts" of many legislations and statutes of all the jurisdictions all over the world.

But it seemed this contention is not carved in stone, as it was challenged in the case law of Union Government (Minister of Railways and Harbours) $v$ Warneke. ${ }^{62}$ TheWarneke case was an appeal against the judgment of the

\footnotetext{
${ }^{51}$ www.saflii.org/za/cases/ZASCA/2000/59.pdf. Accessed 2015/06/15.

52 archive.org/stream/reportscasesdec00maygoog/reportscasesdec00maygoog_djvu.txt. Accessed 2015/06/15.

${ }^{53}$ www.dejure.up.ac.za/index.php/volumes/45...2-2012/106-article-1. Accessed 2015/06/15.

Mkize v Martens 1914 AD 382.

${ }^{54}$ www.dejure.up.ac.za/index.php/volumes/45...2-2012/106-article-1. Accessed 2015/06/15.

${ }^{55}$ www.justice.gov.za/sca/judgments/sca_2002/2001_379.pdf. Accessed 2015/06/15.

${ }^{56}$ Middleton v Automobile Association of South Africa 1932 NPD 451.

${ }^{57}$ archive.org/stream/federalrailwayd01ingegoog/federalrailwayd01ingegoog_djvu.txt. Accessed 2015/06/15. archive.org/stream/reportscasesdec00maygoog/reportscasesdec00maygoog_djvu.txt. Accessed 2015/06/15.

${ }^{58}$ www.justice.gov.za/sca/judgments/sca_2002/2001_379.pdf. Accessed 2015/06/15.

${ }^{59}$ www.justice.gov.za/sca/judgments/sca_2002/2001_379.pdf. Accessed 2015/06/15.

${ }^{60}$ www.justice.gov.za/sca/judgments/sca_2002/2001_379.pdf. Accessed 2015/06/15.

${ }^{61}$ www.elaws.gov.bw/desplaylrpage. $p h p ? i d=610 \& d s p=2$. Accessed 2015/06/15.

${ }^{62} \mathrm{www}$.archive.org/stream/introductionromaO0leeruoft/introductionroma00leeruoft_djvu.txt. Accessed 2015/06/15.

Union Government (Minister of Railways and Harbours) v Warneke 1911 AD 657. apps.ufs.ac.za/courts/dl/system/courts/s...Amod v MMVAF.pdf.Accessed 2015/06/15.
}

DOI: 10.9790/0837-2109134865 $\quad$ www.iosrjournals.org $53 \mid$ Page


Eastern Districts Local Division, dismissing an exception to the plaintiff's declaration by which the plaintiff claimed the sum of 3,000 Pounds Sterling from the Government as damages, alleged to have been caused by the death of his wife through the negligence of the servants of the Government (Minister of Railways and Harbours). The plaintiff's wife was killed in a railway accident, and the plaintiff alleged that by her death, he has been deprived of the comfort and society of his wife and of her assistance in the care, clothing and upbringing of his seven children. ${ }^{63}$

The defendant, the Minister of Railways and Harbours, averred that the plaintiff's declaration discloses no cause of action in law. And, the defendant raises the question on appeal, of whether the loss of the comfort and society of the plaintiff's wife and the loss of her assistance in the care, clothing and upbringing of his children by her, can form a basis for claim for pecuniary damages. It is averred from the case study that such a loss would only constituted ground for rewarding damages if the defendant (Minister of Railways) was found to be negligent. ${ }^{64}$ In order to have a resolution on that legal statement, it is necessary to visit other cases about the dependant's action for loss of support. For example, in Biccard v Biccard and Fryer ${ }^{65}$, it was said that the complete loss of the wife's society constitutes the main element in the estimation of damages, but that was a case in which damages were claimed from an adulterer for the injury done to and the dishonour brought upon, the husband by the adultery of his wife. But the present case, Warneke, is a whole different action founded upon negligence.

Although the husband in the Warneke case is not mentioned as entitled to sue in the case of his wife's death by way of or through negligence, the right of the husband in case of a needy person, whose life had been accustomed during her lifetime to support him, need not to be denied. The duty of supporting children is common to both parents unless one of them was destitute. Supporting must be construed to mean not only feeding or clothing, but also looking after their health and education according to their positions in life. If in the present case the plaintiff's wife was accustomed, during her lifetime, to see to the clothing and upbringing of his children, she did more than her duty towards him and them, and, if by reason of her premature death his expenses in the care and education of the children are increased, then there would be a clear case of damnumreifamiliaris. ${ }^{66}$ On the strength of this legal principle, the judge answered the question raised afore, by stating that the declaration of the plaintiff-husband did disclose a cause of action in law. ${ }^{67}$ In other words, the plaintiff-husband would be entitled to claim as dependant damages for loss of support.

In reciprocity, the judge stated that the allegation that the plaintiff-husband sustained damage because he was deprived of the comfort and society of his wife discloses in itself no cause of action in itself. The judge alleged that the loss of the society and comfort of the wife was a mere matter of sentiment and feeling. The loss could not be compensated for in money as was done in most adultery cases and specifically in the Biccard-case (supra). The judge said that the loss of a wife's comfort and society is a loss which only affects the feelings, and not the property of the husband. ${ }^{68}$ It is not a material loss and affords no ground for patrimonial damages. This reasoning of the judge was wrong. As indicated earlier, there was a move away from the LexAquilia which only accorded an action for damages to property and no provision was made for dependant's action for loss of support. ${ }^{69}$ This archaic legal practice had been altered and under Germanic custom, sentiment and feeling was afforded patrimonial status and therefore brought under the ambit of law for purposes of dependant's action for damages.

\footnotetext{
${ }^{63}$ www.saflii.org.za/za/cases/ZAWCHC/2007/51.html. Accessed 2015/06/15.

${ }^{64}$ www.saflii.org.za/za/cases/ZAWCHC/2007/51.html. Accessed 2015/06/15.

${ }^{65}$ Biccard v Biccard and Fryer 9 C,S.C. 473.

${ }^{66}$ www.saflii.org.za/za/cases/ZAWCHC/2007/51.rtf. Accessed 2015/06/15.

${ }^{67}$ www.elaws.gov.bw/desplaylrpage.php?id=610\&dsp=2. Accessed 2015/06/15.

Union Government (Minister of Railways and Harbours) v Warneke 1911 AD 657.

${ }^{68}$ www.archive.org/stream/introductionroma00leeruoft/introductionroma00leeruoft_djvu.txt. Accessed 2015/06/15.

${ }^{69}$ repository.up.ac.za/bitstream/handle/2263/6760/boezaart_paper_2008.pdf?sequence=1. www.saflii.org/za/cases/ZAECGHC/2011/61.html.
}

DOI: $10.9790 / 0837-2109134865 \quad$ www.iosrjournals.org $\quad 54 \mid$ Page


In revisiting his flaw and after he reached a stalemate, the judge swayed over to the other line of reasoning. After repositioned himself, the judge posed the question of whether the wife owed a duty to the husband to render assistance. If she did, then her death may have caused him patrimonial damage. ${ }^{70}$ If she did not, then she would in the same position as any stranger who might have performed such services, but whose death would have given the plaintiff no cause of action against the wrongdoer [14].

In light of the obligation of pecuniary contributions between spouses, it seemed that every wife is bound to supervise or assist in the care and upbringing of the children of the marriage. The law regards the wife as primarily in charge of the household affairs. This is a legal and sacred duty which she owes not merely to the children, but to her husband, who is entitled to demand her assistance in bearing a burden which the law has placed upon them both. ${ }^{71}$ On the strength of this rendition, there is nothing inconsistent with the principles of law in allowing a husband who can show that his pecuniary expenditure in connection with the maintenance of his children had been directly and necessarily increased due to the death of his wife, to claim damages against the person who has negligently caused her death. ${ }^{72}$ It is, therefore intact, that after the plaintiff-husband had made allowance and assist in the upbringing of the children, that he therefore, be entitled to pecuniary loss in the form of dependant's action for loss of support.

In an obiter dicta, Judge De Villiers visited antiquarian legal sources to buttressed his decision. He cited Ulpian (D. 9, 3) who taught that an action for damages was given ex bono etaequo. Such action should be given to the wife and the children to recover medical expenses and also the value of the services. ${ }^{73}$ If this is so, Judge De Villiers asserted that it is only fair and equitable that a husband should have an action for the damages sustained by him through the loss of his wife. In order to afford the husband a foot to stand on, Judge De Villiers cited Dow $v$ Brown ${ }^{74}$, where a Scotch Court of Session held that a husband was entitled to recover for injury and loss of comfort and domestic happiness by the sudden and violent death of his wife.

The Judge therefore rendered a pioneered verdict when he decided that a husband should be able to recover damages as a solatium for his wounded feelings and for loss of comfort and domestic happiness. This ruling is novel in that it digressed from many other similar cases and is to be regarded anachronistic the practice of law today. But, it also marks a renewal in breaking from the past and set the pace for future legal practice and judicature. The decision of the judge in the Warneke case will eventually be seen as precedent by other judges, because it embraced a bold stand of change and serves as a blue print for engaging in modern day constitutional development. The judge urged though that the rendition in the Warneke case be implemented by the Legislature for purposes of legitimacy.

\subsection{ASSESSMENT OF THE QUANTUM OF DAMAGES FOR DEPENDANT'S ACTION FOR LOSS OF SUPPORT}

In the case law of Archibald $v$ Attorney General $^{75}$ the deceased had been killed unlawfully by a member of the Botswana Defence Force. ${ }^{76}$

At Roman Dutch common law, where a person has wrongfully caused the death of another, the dependants of the deceased are entitled to claim for loss of support sustained as a result of the deceased's death. ${ }^{77}$ The basis of such claim is that the dependants have, as a result of the death of the breadwinner, lost support, which the deceased was under a legal duty to provide for the dependants during his lifetime. ${ }^{78} \mathrm{~A}$ wife and children have a legal right to be maintained by her husband and their father respectively, until a child become self-supporting. In

${ }^{70}$ archive.org/stream/dictionaryterms00abbogoog/dictionaryterms00abbogoog_djvu.txt.

${ }^{71}$ archive.org/stream/dictionaryterms00abbogoog/dictionaryterms00abbogoog_djvu.txt.

72 repository.up.ac.za/bitstream/handle/2263/6760/boezaart_paper_2008.pdf?sequence=1.

${ }^{73}$ archive.org/stream/govuscourtsca9briefs967/govuscourtsca9briefs967_djvu.txt.

${ }^{74}$ Dow v Brown. Scots Revised. Rep 1842-44, vi. Dunlop 534.

${ }^{75}$ Archibald v Attorney General 1989 BLR 421 (HC).

www.elaws.gov.bw/desplaylrpage.php?id=610\&dsp=2. Accessed 2015/06/15.

${ }^{76}$ www.elaws.gov.bw/desplaylrpage.php?id=610\&dsp=2. Accessed 2015/06/15.

${ }^{77}$ www.elaws.gov.bw/desplaylrpage.php?id=610\&dsp=2. Accessed 2015/06/15.

${ }^{78}$ www.elaws.gov.bw/desplaylrpage.php?id=610\&dsp=2. Accessed 2015/06/15.

DOI: $10.9790 / 0837-2109134865 \quad$ www.iosrjournals.org $55 \mid$ Page


the present case of Archibald v Attorney General, the plaintiff as well as her three children were dependant on the deceased. They are therefore entitled to sue for loss of support suffered as a result of the death of the deceased breadwinner. ${ }^{79}$

\subsubsection{The measure of damages}

The measure of damages in delict is that a plaintiff must by monetary compensation be placed in as good a position financially he would have been in, if the delict had not been committed. ${ }^{80}$ With regard to a claim for loss of support, the measure of damages is monetary compensation that would place the dependants in as good a position, as regards maintenance, as they would have been if the deceased had not been killed. ${ }^{81}$

\subsubsection{The sum formula}

\subsubsection{The actuarial method of computation}

In the original particulars of claim in the Archibald case, the plaintiff claimed the sum of P289, 432 for herself and P257, 075 for the three children, totalling P546, 498. ${ }^{82}$ An amendment of the particulars of claim was granted to the plaintiff. According to the amendment, the plaintiff claimed in her personal capacity P444,348 alternatively P411,792, alternatively P385, 749 alternatively P359, 704 alternatively P314, 257; ${ }^{83}$ and in her capacity as mother and natural guardian of her three children she claimed P874, 490, alternatively P839, 478, alternatively P811, 467 alternatively P783, 458 and alternatively P685, 769. ${ }^{84}$ In other words she claimed a total in respect of herself and her children the sum of $\mathrm{P} 1,329,930$, alternatively $\mathrm{P} 1,257,362$, alternatively P1,203,308 alternatively P1,149,254 and alternatively P1,000,026. ${ }^{85}$ In addition, the sum of P6092 was claimed as an adjustment to allow for inflation from the date of the accident to date of trial. All these figures were done by firms of consulting actuaries in South Africa. ${ }^{86}$ These firms employed the year-by-year method of calculations for the determination of the quantum of damages allotted to the plaintiff. $^{87}$

The Presiding Judge in the present case lambasted the Botswana judicature that relied too much on the judicial pronouncements of South African Courts. The actuarial calculations however, have its strong points. ${ }^{88}$ For example, the South African Courts rely heavily on actuarial calculations, so much so that expert evidence of actuaries served as a substitute for the court's own, less sophisticated calculations. Even the Appellate Division in South Africa is averse in interfering with the operation of the actuarial system. The Judge's criticism of the actuarial system of calculation is contingent upon his comparison between South Africa and Botswana. He mentioned that in a country like South Africa, expert actuaries are aplenty and it is not difficult to make use of their services. ${ }^{89}$ But in a country [like Botswana] where they are not readily available, and if it is the rule that such evidence is essential, a litigant may be forced to recruit the services of an actuary abroad. ${ }^{90}$ The import of an actuary might increase the costs of litigation and may unnecessarily prolong the trial. In Botswana and many other developing countries, the majority of the people are poor and experts in certain specialised disciplines are not readily available. ${ }^{91}$ Thus to insist on expert actuarial evidence in such a situation, would not only increase the costs of litigation, but would also cause hardship and unfairness. ${ }^{92}$ The Judge averred that if, for example,

\footnotetext{
${ }^{79}$ www.elaws.gov.bw/desplaylrpage.php?id=610\&dsp=2. Accessed 2015/06/15. Legal Insurance Co Ltd v Botes 1963 (1) SA 608.

${ }^{80}$ www.elaws.gov.bw/desplaylrpage. $p h p$ ? id=610\&dsp=2. Accessed 2015/06/15. Erasmus v Davis 1969 (2) SA 1 (AD).

${ }^{81}$ Legal Insurance Co Ltd v Botes 1963 (1) SA 608.

${ }^{82}$ www.elaws.gov.bw/desplaylrpage.php?id=610\&dsp=2. Accessed 2015/06/15.

${ }^{83}$ www.elaws.gov.bw/desplaylrpage. $p h p ? i d=610 \& d s p=2$. Accessed 2015/06/15.

${ }^{84}$ www.elaws.gov.bw/desplaylrpage. $p h p ? i d=610 \& d s p=2$. Accessed 2015/06/15.

${ }^{85}$ www.elaws.gov.bw/desplaylrpage.php?id=610\&dsp=2. Accessed 2015/06/15.

${ }^{86}$ www.elaws.gov.bw/desplaylrpage.php?id=610\&dsp=2. Accessed 2015/06/15.

${ }^{87}$ Archibald v Attorney General 1989 BLR 421 (HC).

${ }^{88}$ uir.unisa.ac.za/bitstream/handle/10500/2446/thesis.pdf.txt?sequence=2.

${ }^{89}$ www.elaws.gov.bw/desplaylrpage.php?id=610\&dsp=2. Accessed 2015/06/15.

${ }^{90}$ www.elaws.gov.bw/desplaylrpage. $p h p ? i d=610 \& d s p=2$. Accessed 2015/06/15.

${ }^{91}$ www.elaws.gov.bw/desplaylrpage. $p h p ? i d=610 \& d s p=2$. Accessed 2015/06/15.

${ }^{92}$ www.elaws.gov.bw/desplaylrpage. . php ?id=610\&dsp=2. Accessed 2015/06/15.
}

DOI: $10.9790 / 0837-2109134865 \quad$ www.iosrjournals.org $\quad 56 \mid$ Page


actuaries are available, one party in a litigation may be in a position to afford to engage the services of an actuary, whilst the counterparty not be able to afford to pay for that service. ${ }^{93}$ The result is that the rich litigant would have an unfair advantage over his poor opponent. ${ }^{94}$ The Judge therefore opined about the undesirability of Courts in adopting a method of assessment that makes expert actuarial evidence indispensible.

The Judge also contended that the actuarial system of calculation does not form part of the Roman Dutch common law. ${ }^{95}$ In the light of this statement, this Court is thus not obliged to adhere to the actuarial calculations. ${ }^{96}$ The Judge rather stressed that the right measure of for calculation of damages must be applied. But what could that be?

\subsection{The most appropriate method of assessing damages suffered by dependant's for loss of income 4.6.1 The multiplicand/multiplier method of assessment}

The Judge maintained that the most appropriate method for assessing the quantum of damages in the Archibald case should have been the considerations for simplicity and reduction of costs. ${ }^{97}$ This method was evolved by the English Courts and entailed a simple formula which judges and lawyers can easily apply and unnecessary costs should not be incurred by the parties in procuring evidence to prove the quantum of the loss.

Such method might be formulated as thus: The value of the dependency is calculated by taking the present annual figure of the dependency and multiplying it by a figure which, while based upon the number of years that the dependency might reasonably be expected to last, is discounted so as to allow for the fact that a lump sum is being given now instead of periodical payments over the years. ${ }^{98}$ The former figure is called the multiplicand and the latter is called the multiplier. ${ }^{99}$ Further adjustments may be made to the multiplicand or the multiplier on account of a variety of factors, e.g. the probability of future increase or decrease in the annual dependency and the vicissitudes of life. In the English case law, Taylor v O'Conner ${ }^{100}$, the House of Lords discussed the multiplicand/multiplier method of assessment as follows: There are three stages in the normal calculations, namely (1) to estimate the lost earnings, that is, the sums which the deceased probably would have earned but for the fatal accident; (2) to estimate the lost benefit, that is, the pecuniary benefit which the dependants probably would have derived from the lost earnings, and to express the lost benefit as an annual sum over the period of the lost earnings; (3) to choose the appropriate multiplier which, when applied to the lost benefit expressed as an annual sum, gives the amount of the damages, which is a lump sum. ${ }^{101}$

The multiplicand/multiplier method of assessment recognises that there are uncertainties in life. ${ }^{102}$ In other words, cognisance is taken of the fact that experience has taught us that the vicissitudes of life are such that account must be taken of possible contingencies. ${ }^{103}$ A random example of such contingencies are premature death of the deceased; the premature death of the wife or other dependants; that had the deceased survived, he may have been predeceased by his wife; the possibility that had the deceased not died, he may have become ill or rendered incapacitated, or may have become unemployed, or his earning capacity may have reduced. ${ }^{104}$ The Judge took these and other relevant factors in the Archibald-case into consideration in arriving at an assessment by adjusting the multiplicand or the multiplier accordingly. ${ }^{105}$

\footnotetext{
${ }^{93}$ www.elaws.gov.bw/desplaylrpage.php?id=610\&dsp=2. Accessed 2015/06/15.

${ }^{94}$ www.elaws.gov.bw/desplaylrpage.php?id=610\&dsp=2. Accessed 2015/06/15.

${ }^{95}$ www.elaws.gov.bw/desplaylrpage.php?id=610\&dsp=2. Accessed 2015/06/15.

${ }^{96}$ www.elaws.gov.bw/desplaylrpage.php?id=610\&dsp=2. Accessed 2015/06/15.

${ }^{97}$ www.elaws.gov.bw/desplaylrpage.php?id=610\&dsp=2. Accessed 2015/06/15.

${ }^{98}$ www.elaws.gov.bw/desplaylrpage.php?id=610\&dsp=2. Accessed 2015/06/15.

${ }^{99}$ www.elaws.gov.bw/desplaylrpage. $p h p$ ? $i d=610 \& d s p=2$. Accessed 2015/06/15.

${ }^{100}$ www.elaws.gov.bw/desplaylrpage. $p h p$ ? $i d=610 \& d s p=2$. Accessed 2015/06/15.

Taylor v O'Conner [1971] A.C. 115.

${ }^{101}$ www.saflii.org/tz/cases/TZCA/2004/40.pdf

www.elaws.gov.bw/desplaylrpage.php?id=610\&dsp=2. Accessed 2015/06/15.

${ }^{102}$ www.elaws.gov.bw/desplaylrpage. $p h p ? i d=610 \& d s p=2$.

${ }^{103}$ www.elaws.gov.bw/desplaylrpage. $p h p ? i d=610 \& d s p=2$.

${ }^{104} w w w . e l a w s . g o v . b w / d e s p l a y l r p a g e . p h p ? i d=610 \& d s p=2$.

${ }^{105}$ www.elaws.gov.bw/desplaylrpage. php ? id $=610 \& d s p=2$
}

DOI: $10.9790 / 0837-2109134865 \quad$ www.iosrjournals.org $\quad 57 \mid$ Page


The Judge in Archibald relied on the strength of the Taylor case that the applicant and the children were entitled to such a sum as will make good to them the financial loss which they have suffered and will suffer as a result of the death. Future loss, however, is conjectural. But, in spite of the conjectural nature of the assessment, it is stated by Lord Pearce in Mallett v McMonagle ${ }^{106}$, that any assessment must contain elements of reasonable prophecy and arithmetic. ${ }^{107}$ The multiplicand/multiplier method of assessment also provides for the awarding of a lump sum. ${ }^{108}$ The Court recognises, however, that the lump sum may be invested and earn interest which would increase the value of the damages paid and therefore the money available to cover the loss suffered. ${ }^{109}$ The Court therefore makes a discount for the fact that a lump sum is being paid. ${ }^{110}$

The multiplicand is normally assessed by taking into account the deceased's net income at the time of his death and from that calculate the amount expended on his dependents to arrive at the annual dependency. ${ }^{111}$ If the deceased's annual income was likely to increase or decrease after his death, appropriate adjustments are made to the annual dependency. ${ }^{112}$ The annual dependency arrived at after the necessary calculations and adjustments is the multiplicand. ${ }^{113}$

The multiplier is calculated by estimating the number of years that it is anticipated the dependency would have lasted had the deceased not been killed. ${ }^{114}$ The expectation of life of the deceased is taken into consideration. ${ }^{115}$ So also is the expectation of the life span of the dependent. ${ }^{116}$ Other factors to be taken into consideration in the calculation are the trade or profession of the deceased, and the expected working life of the deceased. ${ }^{117}$ It is important to emphasize that the multiplier is not synonymous with the life expectancy of the deceased or his expected working life. The multiplier is not fixed at the same figure as the life expectancy or the expected working life of the deceased. ${ }^{118}$ Those are merely some of the factors that the Court takes into consideration in fixing the multiplier. The prospect of marriage of dependant may also reduce the multiplier. In other words the vicissitudes of life must be born in mind. ${ }^{119}$ All these factors are taken into consideration in increasing or reducing the number of years and thereby arriving at a multiplier appropriate to the particular case. ${ }^{120}$ In this exercise a judge should always bear in mind that his duty is to fix a multiplier making a fair allowance for all the uncertainties and possibilities.

The starting point in any estimate of the number of years that a dependency would have endured, is the number of years between the date of the deceased's death and at that date at which he would have reached normal retiring age. ${ }^{121}$ That falls to be reduced to take account of the change, not only that he might not have lived until retiring age, but also the change that by illness or injury he might have been disabled from gainful occupation. ${ }^{122}$ The former risk can be calculated from available actuarial tables. The latter cannot. ${ }^{123}$ There is also the chance that the widow may be die before the deceased would have reached the normal retiring age or

\footnotetext{
${ }^{106}$ Mallett v McMonagle [1970] A.C. 166.

${ }^{107}$ www.elaws.gov.bw/desplaylrpage. $p h p ? i d=610 \& d s p=2$

${ }^{108}$ www.elaws.gov.bw/desplaylrpage. $p h p ? i d=610 \& d s p=2$

${ }^{109}$ www.elaws.gov.bw/desplaylrpage. $p h p ? i d=610 \& d s p=2$

${ }^{110}$ www.elaws.gov.bw/desplaylrpage. $p h p$ ? $i d=610 \& d s p=2$

${ }^{111}$ www.elaws.gov.bw/desplaylrpage. $p h p$ ? $i d=610 \& d s p=2$

${ }^{112}$ www.elaws.gov.bw/desplaylrpage. $p h p$ ? $i d=610 \& d s p=2$

${ }^{113}$ Mallett v McMonagle [1970] A.C. 166.

${ }^{114}$ www.elaws.gov. bw/desplaylrpage. $p h p$ ? $i d=610 \& d s p=2$

${ }^{115}$ www.elaws.gov.bw/desplaylrpage. $p h p ? i d=610 \& d s p=2$

${ }^{116}$ www.elaws.gov.bw/desplaylrpage. $p h p$ ? $i d=610 \& d s p=2$

${ }^{117}$ www.elaws.gov.bw/desplaylrpage. $p h p$ ? $i d=610 \& d s p=2$

${ }^{118}$ www.elaws.gov.bw/desplaylrpage. $p h p ? i d=610 \& d s p=2$

${ }^{119}$ www.elaws.gov.bw/desplaylrpage.php?id=610\&dsp=2

${ }^{120}$ www.elaws.gov.bw/desplaylrpage.php?id=610\&dsp=2

${ }^{121}$ uir.unisa.ac.za/bitstream/handle/10500/2446/thesis.pdf.txt?sequence=2.

${ }^{122}$ www.elaws.gov.bw/desplaylrpage.php?id $=610 \& d s p=2$

${ }^{123}$ www.elaws.gov.bw/desplaylrpage.php?id=610\&dsp $=2$
}

DOI: 10.9790/0837-2109134865 www.iosrjournals.org


that she may remarry and thus replace her dependency from some other source which would not have been available to her had her husband lived. ${ }^{124}$

When the multiplicand and the multiplier have been arrived at, they are multiplied to arrive at a figure. ${ }^{125}$ That figure may be further adjusted to arrive at a figure which the Court (in the Archibald case) considers fair and reasonable in the circumstances. ${ }^{126}$ The multiplicand/multiplier method of assessment denotes that the damages awarded must be fair and reasonable. ${ }^{127}$ It behoved a judge to try to fix a figure which is neither unfair to the recipient nor to the one who has to pay.

With regard to the assessment of damages, the deceased's annual salary had been increased to P30,360, i.e. P2,560 per month. ${ }^{128}$ He was receiving P200 per month as rent allowance. ${ }^{129}$ He was also entitled to the use of the firm's vehicle and 25 per cent tax free gratuity at the end of his two year contract. In arithmetic terms: the taxable items were:

Salary P30,360

Housing allowance $\quad$ P2,400

Private use of car P2,000 (it is not stated in the report how the figure was arrived at - the judge however assess the value of the use of the car at P2,000).

Total: $\underline{\mathrm{P} 34,760^{130}}$

Allowing for income tax: the judge put the taxable income at P17,000.

Adding one half of the gratuity due to the net taxable income, the result would be as follows:

$\mathrm{P} 17,000$

$$
\begin{aligned}
& \text { P3,795 } \\
& \text { P20,795(ANNUAL INCOME) }{ }^{131}
\end{aligned}
$$

The judge therefore arrived at net annual income of P20, 795. ${ }^{132} \mathrm{He}$ is to consider the dependency of the plaintiff and the three children on the basis of that net annual income. ${ }^{133}$ The judge decided to assess the dependency of the plaintiff at two-sevenths and that of each child at one-seventh of the net income. ${ }^{134}$ In the light of this contention he fix the dependency of the plaintiff at the date of death of the deceased at P5941,42 and that of each of the three children at P2970,71, which adds to a total dependency of P14,853,55.

\subsubsection{What would be the appropriate multiplier?}

In fixing the appropriate multiplier, the judge in the Archibald case has to bear in mind the vicissitudes and uncertainties of life. ${ }^{135}$ The conventional multiplier when the deceased died in his twenties is 16 years. This multiplier is contingent upon a dictum in the case of Robertson v Lelestrange and Another. ${ }^{136}$ In this case it is established that where the deceased was aged 29 and a half years and it was accepted that the expectation of life of the deceased was 72 at the date of death and that his working life was up to the age of 65 years, the multiplier was fixed at 16 years. ${ }^{137}$ But the judge, ruled that the older the deceased, the lower the multiplier - the deceased was 35 years old during his untimely death. ${ }^{138}$ The Judge therefore fixed the multiplier in this case at 13 years

\footnotetext{
${ }^{124}$ www.elaws.gov.bw/desplaylrpage. php?id=610\&dsp $=2$ Archibald v Attorney General.

${ }^{125}$ www.elaws.gov.bw/desplaylrpage.php?id=610\&dsp $=2$

${ }^{126}$ uir.unisa.ac.za/bitstream/handle/10500/2446/thesis.pdf.txt?sequence=2.

${ }^{127}$ www.elaws.gov.bw/desplaylrpage. php? $i d=610 \& d s p=2$

${ }^{128}$ www.elaws.gov.bw/desplaylrpage. $p h p$ ? $i d=610 \& d s p=2$

${ }^{129}$ www.elaws.gov.bw/desplaylrpage. $p h p$ ? $i d=610 \& d s p=2$

${ }^{130}$ www.elaws.gov.bw/desplaylrpage. $p h p ? i d=610 \& d s p=2$

${ }^{131}$ www.elaws.gov.bw/desplaylrpage. $p h p ? i d=610 \& d s p=2$

${ }^{132}$ www.elaws.gov.bw/desplaylrpage. $p h p$ ? $i d=610 \& d s p=2$

${ }^{133}$ www.elaws.gov.bw/desplaylrpage. $p h p$ ? $i d=610 \& d s p=2$

${ }^{134}$ www.elaws.gov.bw/desplaylrpage. php?id=610\&dsp $=2$

${ }^{135}$ www.elaws.gov.bw/desplaylrpage. php ? $i d=610 \& d s p=2$

${ }^{136}$ Robertson v Lelestrange and Another [1985] 1 All E.R. 950.

${ }^{137}$ www.elaws.gov. bw/desplaylrpage. $p h p$ ? $\mathrm{id}=610 \& \mathrm{dsp}=2$

${ }^{138}$ www.elaws.gov.bw/desplaylrpage. $p h p ? i d=610 \& d s p=2$
} 
from the date of death. The Judge finally reduced the multiplier to 10 years. ${ }^{139}$ This moved is bolstered by the prospect of the remarriage of a widow dependant - this will impact on the multiplier. ${ }^{140}$ By remarrying the widow-dependant would become entitled to be supported by her new husband. ${ }^{141}$ In this case the parties have agreed that a discount of 55 per cent be allowed from the plaintiff's claim in respect of her future prospects for remarriage. $^{142}$

The Judge in Archibald, will now proceed to calculate the award of damages on the basis of the multiplicand and the multipliers. He fixed the multiplicand at P18,000. ${ }^{143}$ Applying the agreed ratio of one to the plaintiff and one-half each of the three children, the multiplicand of the plaintiff would work out at P7200, and that of each of the three children at P3,600. ${ }^{144}$ Applying a multiplier of 10 to the multiplicand of the plaintiff, the damages payable would amount to P72,000. And applying a multiplier of 13 to the multiplicand of each child, the damages payable to each child would amount to P46,800, totalling P140,400. ${ }^{145}$ The total for the plaintiff and the three children is therefore P212,400.

The Judge mentioned that it is common cause that the share of the estate of the deceased devolving on the plaintiff and the children, being a benefit accruing to them as a result of the death of the deceased, should be deducted from the damages of the estate. The Judge proceeded and deduct the sum of P10,745 from the total award leaving a balance of P201,655. ${ }^{146}$

\section{CONSTITUTIONAL DEVELOPMENTAL APPROACH}

The Constitution of South Africa, Act 108 of 1996 is the supreme law of the land. ${ }^{147}$ Any conduct or law which is inconsistent with it is invalid. ${ }^{148}$ Certain fundamental rights, to which juristic persons are also entitled, are entrenched in Chapter 2 (the Bill of Rights) of the Constitution. ${ }^{149}$ Chapter 2 is applicable to all law - therefore also the law of delict - and does not only vertically bind the state, but also horizontally binds all natural and juristic persons. ${ }^{150}$ When interpreting the provisions of Chapter 2, the courts must promote the values that underlie an open and democratic society based on human dignity, equality and freedom. ${ }^{151}$ In the interpretation of any legislation, and when developing both the common and customary law, the courts must promote the spirit, purport and objects of the Bill of Rights. ${ }^{152}$ In Carmichele v Minister of Safety and Security (Centre for Applied Legal Studies Intervening) ${ }^{153}$, the Constitutional Court stated that where the common law deviates from the spirit, purport and objects of the Bill of Rights, the courts have a general duty to develop the common law to eliminate the deviation.

The Constitutional values relevant to the extension of the common law sought by are those contained in ss 9 [24] and 10 [24] of the Constitution of South Africa. ${ }^{154}$ In Du Plessis v Road Accident Fund ${ }^{155}$ the dependant's

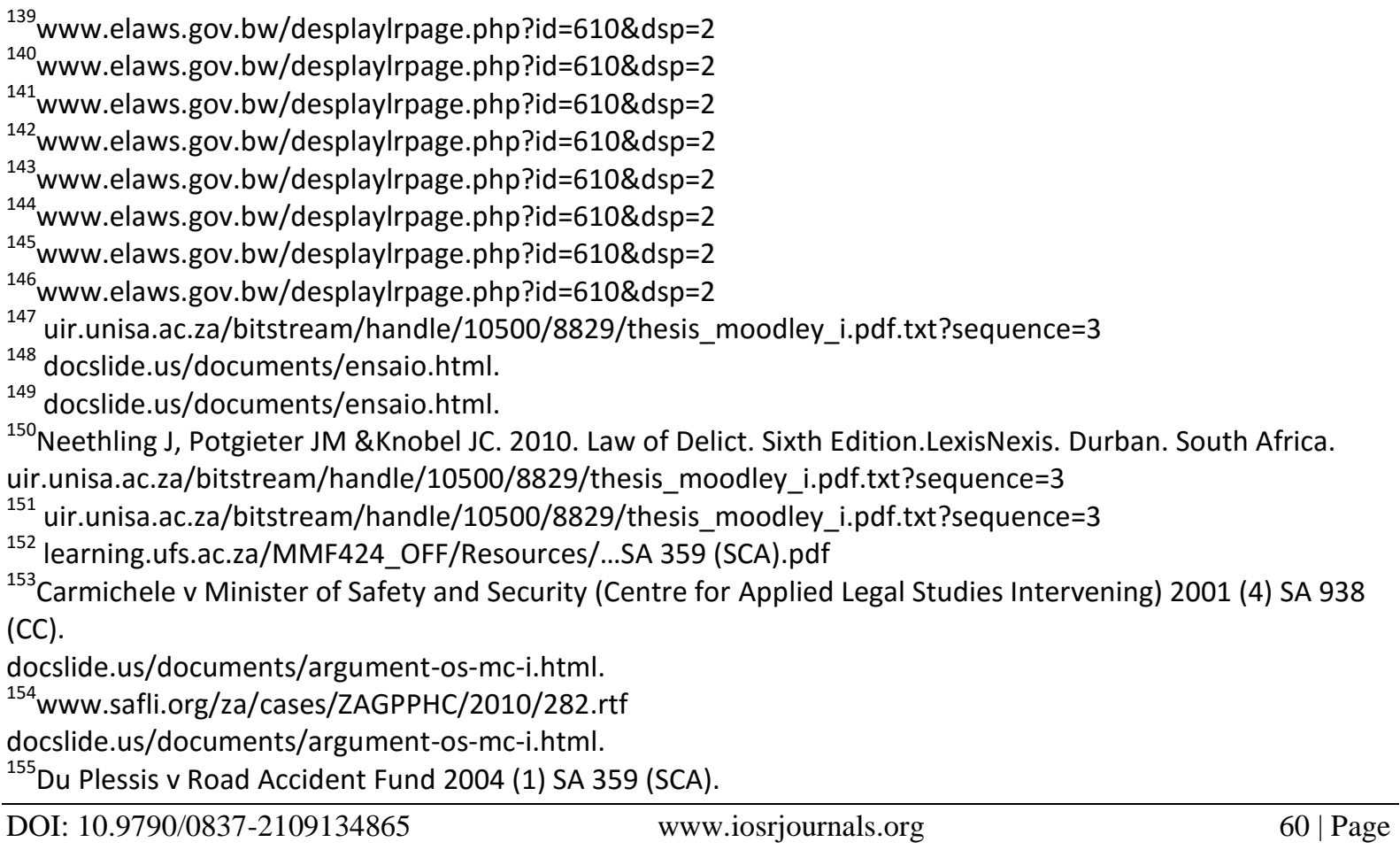


action was extended to a partner in a same-sex permanent life relationship. ${ }^{156}$ The partner was killed in a motor vehicle accident and a claim for damages (loss of support) was allowed against the defendant Road Accident Fund (RAF) by the surviving partner. ${ }^{157}$

The defendant's (RAF) argument was that the plaintiff's claim for loss of support was not maintainable in law. ${ }^{158}$ The plaintiff requested that the common law definition of marriage which required that a union be between a man and a woman, also be extended to persons of the same sex. ${ }^{159}$ It meant that the common law action for damages for loss of support should be developed to include a person such as the plaintiff. ${ }^{160}$ It was trite that a widow who was legally married to the deceased was entitled to bring an action for the loss of support for the unlawful killing of her husband. ${ }^{161}$ It was the plaintiff's case that the common law should be developed to place him in the same position. ${ }^{162}$

The judge said in Du Plessis that a marriage gives rise to a reciprocal duty of support on the part of the parties to that marriage. ${ }^{163}$ However, the law currently only recognises marriages that are conjugal relationships between people of the opposite sex. ${ }^{164}$ There is, nevertheless, in the words of Judge Ackermann in National Coalition for Gay and Lesbian Equality and Others v Minister of Home Affairs and Others ${ }^{165}$, as cited in para. 12 of the $\mathrm{Du}$ Plessis case another form of life partnership which is different from marriage as recognised by law. ${ }^{166}$ This form of life partnership is represented by a conjugal relationship between two people of the same sex. ${ }^{167}$ The duty to support on the part of the deceased was further corroborated when it is stated in a dictum of National Coalition in Du Plessis that the plaintiff and the deceased lived together as if they were legally married in a stable and permanent relationship until the deceased was killed some 11 years later. ${ }^{168}$ They were accepted by their family and friends as partners in such a relationship. ${ }^{169}$ They pooled their income and shared their family responsibilities and each of them made a will in which the other partner was appointed the sole heir. ${ }^{170}$ When the plaintiff was medically boarded, the deceased expressly stated that he would support the plaintiff financially and in fact did so until he died. ${ }^{171}$

In the light of this, the court in Du Plessis had to decide whether the killing of the deceased should be considered to have been a wrongful act against the plaintiff. ${ }^{172}$ The Judge answered this question by relying on constitutional premises in the light of the prevailing boni mores demands of society. ${ }^{173}$ The judge adopted the following formulation of the nature of the enquiry. ${ }^{174} \mathrm{He}$ asserted that the plaintiff's invaded interest is deemed

www.saflii.org/za/cases/ZASCA/2003/86.pdf

${ }^{156}$ www.saflii.org/za/cases/ZAGPPHC/2010/282.rtf

${ }^{157}$ learning.ufs.ac.za/MMF424_OFF/Resources/...SA 359 (SCA).pdf

${ }^{158}$ learning.ufs.ac.za/MMF424_OFF/Resources/...SA 359 (SCA).pdf

${ }^{159}$ www.saflii.org/za/cases/ZAGPPHC/2010/282.rtf

${ }^{160}$ www.saflii.org/za/cases/ZAGPPHC/2010/282.rtf

${ }^{161}$ www.saflii.org.za/za/cases/ZASCA/2003/86.html

${ }^{162}$ www.saflii.org/za/cases/ZASCA/2011/31.html

${ }^{163}$ learning.ufs.ac.za/MMF424_OFF/Resources/...SA 359 (SCA).pdf

${ }^{164}$ www.saflii.org/za/cases/ZAGPPHC/2010/282.rtf

${ }^{165}$ National Coalition for Gay and Lesbian Equality and Others v Minister of Home Affairs and Others 2000 (2) SA 1 (CC).

${ }^{166}$ www.scielo.org.za/scielo.php?script=sci_arttext\&pid=S1021-545X2013000200003

www.saflii.org.za/za/cases/ZASCA/2003/86.html

${ }^{167}$ www.saflii.org.za/za/cases/ZAGPJHC/2014/432.pdf

${ }^{168}$ www.saflii.org.za/za/cases/ZASCA/2003/86.html

${ }^{169}$ www.saflii.org.za/za/cases/ZAGPJHC/2014/432.pdf

${ }^{170}$ www.saflii.org/za/cases/ZAGPPHC/2010/282.rtf

${ }^{171}$ learning.ufs.ac.za/MMF424_OFF/Resources/...SA 359 (SCA).pdf

${ }^{172}$ learning.ufs.ac.za/MMF424_OFF/Resources/...SA 359 (SCA).pdf

${ }^{173}$ learning.ufs.ac.za/MMF424_OFF/Resources/...SA 359 (SCA).pdf

${ }^{174}$ www.saflii.org.za/za/cases/ZASCA/2003/86.html

DOI: $10.9790 / 0837-2109134865$

www.iosrjournals.org

$61 \mid$ Page 
worthy of legal protection against negligent interference by conduct of the kind alleged against the defendant. ${ }^{175}$ The judge held that the constitutional values relevant to the extension of the common law are those contained in ss 9 and 10 of the Constitution of South Africa. Bolstered by this sentiment, the right to dignity is emphasised in Dawood, Shalabi, Thomas and Others $v$ Minster of Home Affairs. ${ }^{176}$ The Constitution asserts dignity to contradict our past in which human dignity for black South Africans was routinely and cruelly denied. ${ }^{177}$ It asserts it too to inform the future, to invest in our democracy respect for the intrinsic worth of all human beings. ${ }^{178}$ Human dignity therefore informs constitutional adjudication and interpretation at a range of levels. It is a value that informs the interpretation of many, possibly all rights. ${ }^{179}$ Section 10 , makes it plain that dignity is not only a value fundamental to our Constitution, it is a justiciable and enforceable right that must be respected and protected.

In Khan $v$ Khan $^{180}$ it is found that there is a duty on a husband to maintain his ex-wife to whom he was married according to Muslim rites in a situation where the marriage is in fact polygamous. ${ }^{181}$ The judge related that the preamble to the Maintenance Act 1998 (Act 99 of 1998) emphasised the establishment of a fair and equitable maintenance system premised on the fundamental rights afforded in the Constitution of South Africa. ${ }^{182}$ He further contended that the common law duty of support was a flexible concept developed and extended over time by the Courts to cover a wide range of relationships. The questions which Courts have considered in determining whether a particular relationship gave rise to a duty of support included whether the complainant required financial aid and whether the relationship between the parties created a duty to maintain. ${ }^{183}$ The judge in Khan concluded by saying that despite the lack of a formal marriage, the Constitutional Court had in Satchwell v President of the Republic of South Africa and Another ${ }^{184}$ found that duties of reciprocal support could be inferred from, inter alia, how others perceived the couple, whether family responsibilities were shared, and whether the couple had provided for one another upon death.

In light of the interpretation of statutes (Maintenance Act) vis-à-vis the Constitution, the words of Justice Langa in the case of Investigating Directorate: Serious Economic Offences and Others v Hyundai Motor Distributors (Pty) Ltd and Others: In re Hyundai Motor Distributors (Pty) Ltd and Others $v$ Smit and Others ${ }^{185}$ needed to be pondered over. He alleged that all statutes must be interpreted through the prism of the Bill of Rights. ${ }^{186}$ All law-making authority must be exercised in accordance with the Constitution. ${ }^{187}$ The Constitution is located in a history which involves a transition from a society based on division, injustice and exclusion from the democratic process to one which respects the dignity of all citizens, and includes all in the process of governance. ${ }^{188}$ As such, the process of interpreting the Constitution must be recognise the context in which we find ourselves and the Constitution's goal of a society based on democratic values, social justice and fundamental human rights.

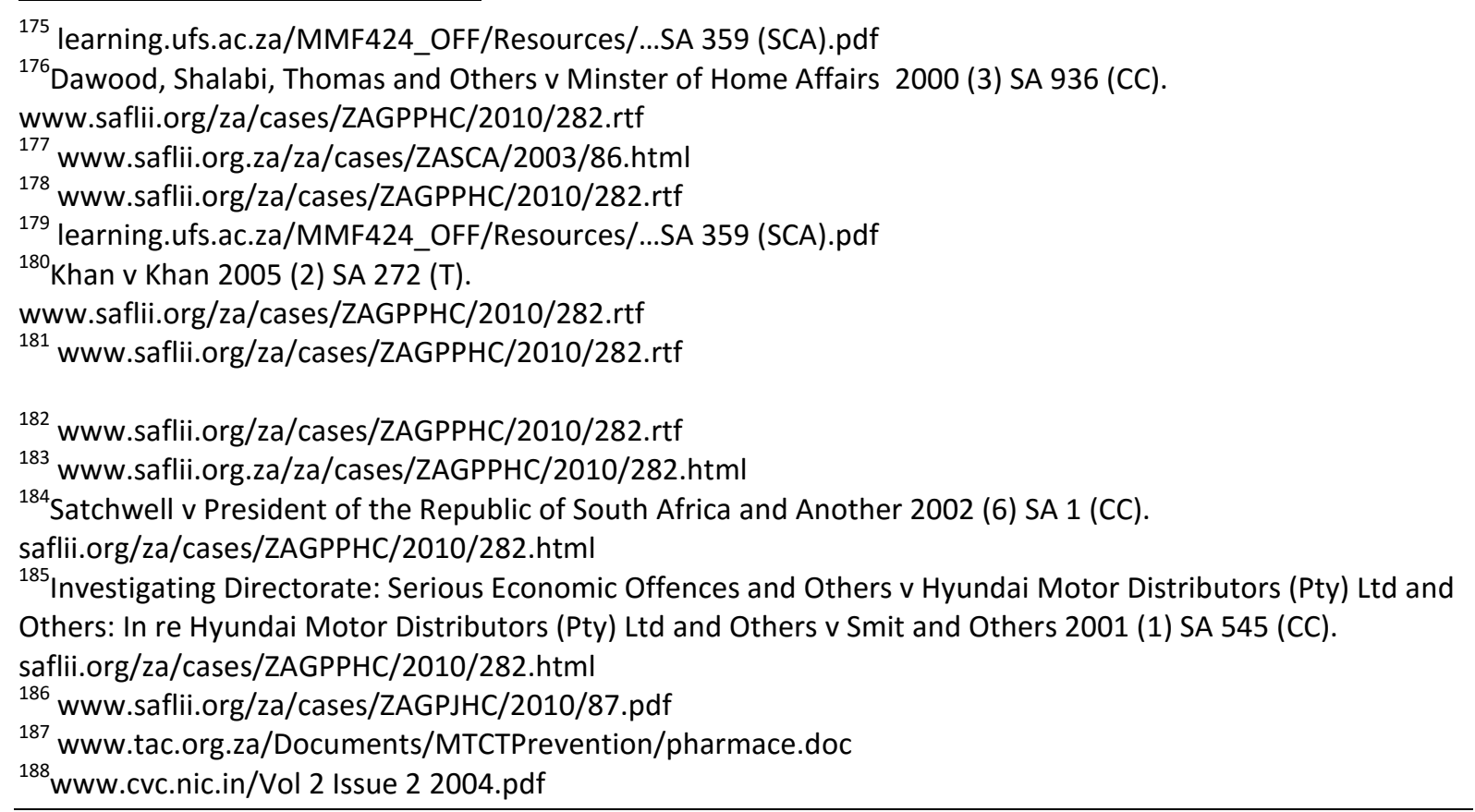

DOI: 10.9790/0837-2109134865 $\quad$ www.iosrjournals.org $\quad 62 \mid$ Page


In Daniels $v$ Campbell and Others ${ }^{189}$, Justice Ngcobo made the following comment (which also reverberated earlier in the text) with regard to the proper approach to legislative interpretation: "Section 39(2) of the Constitution contains an injunction on the interpretation of legislation. ${ }^{190}$ It requires courts when interpreting any legislation 'to promote the spirit, purport and objects of the Bill of Rights. ${ }^{191}$ Consistent with this interpretative injunction, where possible, legislation must be read in a manner that gives effect to the values of our constitutional democracy. Thus where legislation is capable of more than one plausible construction, the one which brings the legislation within constitutional bounds must be preferred."192

In recapitulation, the common law duty of support is a flexible concept that has been developed and extended over time by our Courts to cover a wide range of relationships such as grandparents vis-à-vis grandchildren, and vice versa, children to their parents, brothers and sisters to each other, divorcees towards each other, same-sex partnerships and most recently extending the duty of support of an illegitimate child to its paternal grandparents. ${ }^{193}$

\section{CONCLUSION}

It is evident from the tenor of this study that a dependant derived his or her right of action of loss of support from the fact that he or she has been injured by the death of the deceased or breadwinner and that the respondent is responsible for it. This study has answered the research question posed about the negligence of the breadwinner, whether such condition rendered the dependant's action for loss of support null and void. In the Lee case the Court held that the negligence of the husband or breadwinner did not render the dependant's action for loss of support a nullity. The widow's or dependant's loss of support is derived from the Germanic custom that allow for patrimonial loss also. The Germanic principles of wergeld and zoengeld entailed that there are no grounds on which negligence of the husband or breadwinner can be imputed to his widow. This idea is in line with the modern day Constitution of South Africa in which the dependant's action for loss of support have been extended to illegitimate, polygamous and Islamic and gay and lesbian relationships.

\section{BIBLIOGRAPHY}

[1] apps.ufs.ac.za/courts/dl/system/courts/s...Amod v MMVAF.pdf.Accessed 2015/06/15.

[2] archive.org/stream/federalrailwayd01ingegoog/federalrailwayd01ingegoog_djvu.txt. 2015/06/15

[3] archive.org/stream/reportscasesdec00maygoog/reportscasesdec00maygoog_djvu.txt. 2015/06/15

[4] archive.org/stream/dictionaryterms00abbogoog_djvu.txt. Accessed 2015/06/15.

[5] archive.org/stream/govuscourtsca9briefs967/govuscourtsca9briefs967_djvu.txt. Accessed 2015/06/15.

[6] Archibald v Attorney General 1989 BLR 421 (HC).

[7] Biccard $v$ Biccard and Fryer 9 C.S.C 473.

[8] Carmichele v Minister of Safety and Security (Centre for Legal Studies Intervening) 2001 (4) SA 938 (CC).

[9] Daniels $v$ Campbell and Others 2004 (5) SA 331 (CC).

[10] Dawood, Shalabi, Thomas and Others v Minister of Home Affairs 2000 (3) SA 936 (CC).

[11] De Groot, H. De Jure Belli ac Pacis. Paris: ApudNicalaumBuon. MDCXXV (The French National Library).

[12] Dow v Brown Scots Revised Rep. 1842-44, VI. Dunlop 534.

[13] Erasmus v Davis 1969 (2) SA 1 (AD).

[14] docslide.us/documents/ensaio.html. Accessed 2015/06/15.

[15] docslide.us/documents/argument-os-mc-i.html. Accessed 2015/06/15.

[16] Du Plessis v Road Accident Fund 2004 (1) SA 359 (SCA).

\footnotetext{
${ }^{189}$ Daniels v Campbell and Others 2004 (5) SA 331 (CC).

www.saflii.org/za/cases/ZAGPPHC/2010/282.rtf

${ }^{190}$ www.saflii.org/za/cases/ZAGPPHC/2010/282.rtf

${ }^{191}$ saflii.org/za/cases/ZAGPPHC/2010/282.html

192 www.saflii.org/za/cases/ZAGPPHC/2010/282.rtf

${ }^{193}$ www.saflii.org/za/cases/ZASCA/2008/141.rtf
}

DOI: $10.9790 / 0837-2109134865$ 
[17] Evins v Shield Insurance Co Ltd 1980 (2) SA 814 (A).

[18] Hafiza Ismael Amod v Multilateral Motor Vehicle Accidents Fund. Case No.: 444/98 (29 September 1999).

https://en.wikipedia.org/wiki/South_African_law_of_delict. Accessed 2015/06/15.

https://quizlet.com/43647443/law-of-delict-flash-cards/ Accessed 2015/06/15.

https://indiankanoon.org/doc/1332665/. Accessed 2015/06/15.

https://www.coursehero.com/file/p17g4nr/...ted-by-the-deceased/. Accessed 2015/06/15.

Hulley v Cox 1923 AD 234.

Investigating Directorate: Serious Economic Offences and Others v Hundai Motor Distributors (Pty) Ltd and Others: In Re Hyundai Motor Distributors (Pty) Ltd and Others $v$ Smit and Others 2001 (1) SA 545 (CC).

Khan $v$ Khan 2005 (2) SA 272 (T).

Lambrakis $v$ Santam Ltd 2002 (3) SA 710 (SCA).

learning.ufs.ac.za/MMF424_OFF/Resources/...SA 359 (SCA).pdf.Accessed 2015/06/15.

Legal Insurance Co. Ltd v Botes 1963 (1) SA 608.

Mallet v McMonagle [1970] A.C. 166.

MacDonald and Others $v$ Road Accident Fund (453/2011) [2012] ZASCA 69, [2012] 4 All SA 15 (SCA) (24 May 2012).

Middleton v Automobile Association of South Africa 1932 NPD 451.

Mkize v Martens 1914 AD 382.

National Coalition for Gay and Lesbian Equality and Others v Minister of Home Affairs and Others 2000 (2) SA 1 (CC).

Neethling J, Potgieter JM, Knobel JC. Law of Delict.Sixth Edition. Durban: Lexis Nexis. 2010.

Paixao v Road Accident Fund (640/2011), [2012] ZASCA 130 (26 September 2012).

repository.up.ac.za/bitstream/handle/2263/6760/boezaart_paper_2008.pdf?sequence=1. Accessed 2015/06/15.

Robertson v Lelestrange and Another [1985] 1 All E.R. 950.

saflii.org/za/cases/ZAWCHC/2011/215.html. Accessed 2015/06/15.

Satchwell v President of the Republic of South Africa 2002 (6) SA 1 (CC).

South African Railways and Harbours v Marais 1959 (4) SA 610 (A).

Taylor v O'Conner [1971] A.C. 115.

uir.unisa.ac.za/bitstream/handle/10500/2446/thesis.pdf.txt?sequence=2. Accessed 2015/06/15.

uir.unisa.ac.za/bitstream/handle/10500/8829/thesis_moodley_i.pdf.txt?sequence=3. Accessed 2015/06/15.

Union Government (Minister of Railways and Harbours) v Warneke 1911 AD 657.

Union Government (Minister of Railways) v Lee 1927 AD 202.

www.dejure.up.ac.za/index/php/volumes/45...2-2012/106-article-1. Accessed 2015/06/15.

www.justice.gov.za/sca/judgments/sca-1999/1999-santam.pdf. Accessed 3025/06/15.

www.tac.org.za/Documents/MTCTPrevention/pharmace.doc. Accessed 2015/06/15.

www.cvc.nic.in/vol2Issue22004.pdf. Accessed 2015/06/15.

www.scielo.org.za/scielo/php?script=sci_arttext\&pid=s1021-545x2013000200003. Accessed 2015/06/15.

www.saflii.org/za/cases/ZASCA/2003/86.pdf. Accessed 2015/06/15/.

www.saflii.org.za/za/cases/ZAGPPHC/2010/282.html. Accessed 2015/06/15.

www.saflii.org/za/cases/ZAGPJHC/2010/87.pdf. Accessed 2015/06/15.

www.saflii.org/za/cases/ZASCA/2011/31.html. Accessed 2015/06/15.

www.saflii.org/tz/cases/TZCA/2004/40.pdf. Accessed 2015/06/15.

www.saflii.org.za/za/cases/ZAWCHC/2007/51.rtf. Accessed 2015/06/15.

www.saflii.org/zacases/ZAGPPHC/2010/282.rtf. Accessed 2015/06/15.

www.saflii.org.za/za/cases/ZASCA/2003/86.html. Accessed 2015/06/15.

www.saflii.org.za/za/cases/ZAGPJHC/2014/432.pdf. Accessed 2015/06/15.

www.justice.gov.za.sca.judgments/sca_2002/2001_379.pdf. Accessed 2015/06/15.

www.justice.gov.za/sca/judgments/sca_1999/1998_444_amod.pdf. Accessed 2015/06/15.

www.elaws.gov.bw/desplaylrpage.php?id=610\&dsp=2. Accessed 2015/06/15.

www.archive.org/stream/ahistorygermani00walzgoog/ahistorygermani00walzgoog_djvu.txt.

Accessed 2015.06/15.

DOI: $10.9790 / 0837-2109134865$

www.iosrjournals.org

$64 \mid$ Page 
www.archive.org/stream/introductionroma00leeruoft/introductionroma00leeruoft_djvu.txt.

Accessed 2015/06/15

www.saflii.org/za/cases/ZASCA/2000/59.pdf. Accessed 2015/06/15.

www.saflii.org.za/za/cases/ZAWCHC/2007/51.html. Accessed 2015/06/15.

www.saflii.org/za/cases/ZASCA/2008/141.html. Accessed 2015/06/15.

www.saflii.org.za/za/cases/ZAGPPHC/2009/16.html. Accessed 2015/06/15.

www.saflii.org/za/cases/ZAECGHC/2011/61.html. Accessed 205/06/15.

www.saflii.org/za/cases/ZASCA/2012/130.rtf. Accessed 2015/06/15. 